\title{
Accounting Information Systems in an ERP Environment and Tunisian Firm Performance
}

Hazar Daoud. University of Sfax. Tunisia daoudhazar@ planet.tn

Mohamed Triki. University of Sfax. Tunisia. Mohamed.triki@mes.rnu.tn

\begin{abstract}
ERP system adoption has largely marked the evolution of accounting information systems (AISs). Modern AISs have great potential to influence business performance. The purpose of this study is to examine the influence of the accounting information system in an ERP environment on firm performance. We investigate the direct effects of top management involvement and external expertise on the AIS. We also examine the interaction effect of accounting staff competency with the AIS and test its impact on firm performance improvement. We conduct an empirical study of 102 Tunisian firms adopting ERP systems. We use the partial least square (PLS) approach for hypothesis testing. The results indicate that top management involvement and external expertise have an impact on the AIS. Furthermore, they show that the accounting techniques used after ERP system adoption influence firm performance. The interaction effect of accounting staff competency with the AIS has a positive impact on firm performance improvement.
\end{abstract}

Key words: Accounting information system, ERP system, contingency factors, firm performance.

\section{INTRODUCTION}

For years, financial accounting has been considered a formal and a widespread source of information within organizations (Chapellier, 1994). According to standards and accounting rules, financial accounting provides a representation of the financial situation of companies. This representation is communicated through financial statements at the end of each accounting period and in accordance with legal requirements and tax regulations. 
Thus, accounting information systems (AISs) have been limited to preparing financial statements for legal purposes and producing historical accounting and financial information (Mia, 1993).

The introduction of information technologies has necessitated the redefinition of such information systems. In fact, Chenhall (2003) argued that the mission of the AIS has risen from the simple provision of formal and financial information to encompass a broader range of information. The use of enterprise resource planning (ERP) technology has facilitated the embodiment of this new vision.

An ERP is a complex set of computer applications designed to integrate the processes and functions within the same company. This system is able to present a holistic vision of the company's business by sharing a common and integrated database. In the era of the ERP system, the AIS has become richer. The amount of information has become more important, and the data are updated and relevant. We see, thus, the use of new management accounting techniques that meet the internal needs of the company. Thus, the AIS provides both historical and forecasting accounting information that covers financial accounting, management control and financial analysis. We wonder, at this stage, about the ability of such an information system to improve business performance.

Previous researchers have tried to test the contribution of accounting information systems to business performance (Affès and Chabchoub, 2007; Boulianne, 2007; Stepniewski et al., 2008; Karruddin et al., 2010; Grande et al., 2011). While these studies contributed rigorously to the accounting literature, they did not use models from the information systems literature to explain companies' performance. The models of Delone and McLean (1992) and Gable et al. (2003) are examples of these information system success models. Therefore, in this research, we try to adopt these models to study accounting information systems.

In addition, we found that most studies have not dealt with information systems in the context of advanced technologies such as ERP. In fact, the combination of accounting information systems and this technology seems to be obvious. It would also be logical to think that the adopting companies of such systems expect some benefits from this implementation. Thus, our study focuses on accounting information systems when they are supported by ERP technology and assesses their effects on business performance. 
On the other hand, studies following the contingency theory have demonstrated the existence of a relationship between organizational and environmental factors and organizational performance. So, we aim to test the following question:

How and to what extent does the implementation of an accounting information system in an ERP context influence corporate performance?

We propose to develop a research model to study the direct and interaction effects that may exist between the AIS, the contingency factors and the business performance.

This study is interesting on three levels. On the theoretical level, this research will highlight the participation of certain actors in the determination of accounting information systems. These actors are top management, external experts and accounting staff. This study will also attempt to contribute to the general debate on the introduction of ERP technology to accounting information systems and to assess its contribution to business performance.

On the methodological level, this research will analyse the direct and moderating effects between accounting information system characteristics in an ERP environment and contingency factors and corporate performance. The validation method used for this purpose is structural equation modelling.

On a practical level, if a link could be established between the contingency factors and the accounting information system characteristics, it would be important for business leaders to devote more time to analysing their own accounting information systems and to providing, accordingly, the resources needed to achieve better performance.

\section{THEORETICAL FOUNDATION}

\subsection{The information system success models}

\subsubsection{DeLone and McLean's model (1992)}

DeLone and McLean's model is one of the information system success models. These authors aimed to synthesize the previous research on information system success and present a more coherent basis for future research (DeLone and McLean, 2003). Ballantine et al. (1998) considered the model of DeLone and 
McLean (1992) as one of the most complete and best-known models. In fact, it reinforces the previous research and presents a plausible classification efficiency measure of information systems. This model has been considered by many researchers as an appropriate basis for future theoretical and empirical research.

A literature review identified that Mushayt (2000) and Ismail (2009) used Delone and McLean's model in accounting information systems. Mushayt (2000) showed that this model is valid, one-dimensional and reliable in an accounting information system context.

In their model, Delone and McLean (1992) proposed that the success of information systems is determined by the information system quality (the technical quality of the system) and the output quality of the information system (the quality of information produced). These dimensions influence the use level and user response to the information system (user satisfaction). As a result, the user attitude (individual impact) and organizational performance (organizational impact) are influenced (Figure 1).

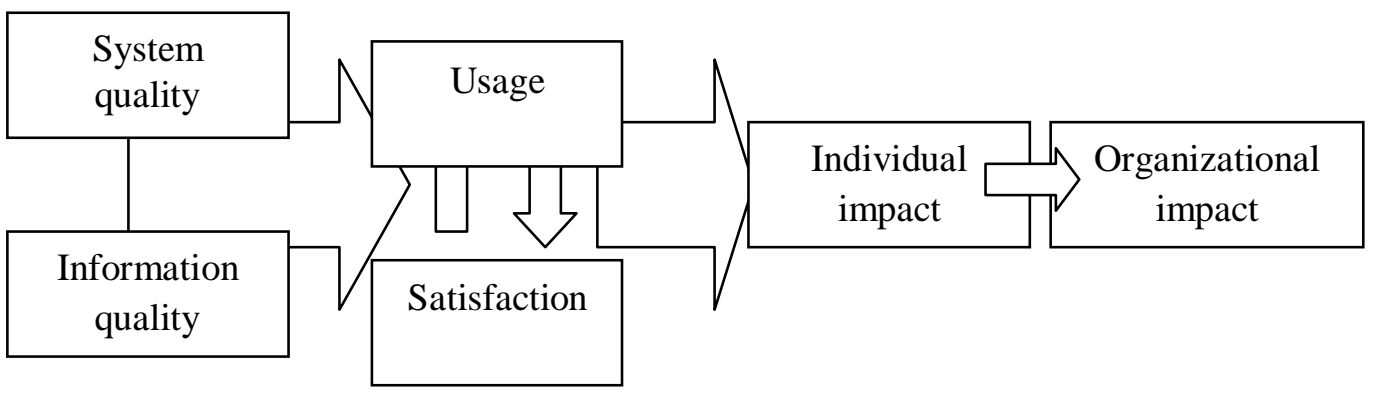

Figure 1: Delone and McLean's model (1992)

DeLone and McLean's model has been criticized by some authors. Indeed, this model is specific to contexts of voluntary use of information technology. The usage variable remains a success variable of information systems if the user himself decides to adopt or reject the technology. However, for mandatory uses, such as for ERP systems, the use of the technology is obvious. The success of information systems cannot, therefore, be measured by usage. Considering this criticism, Gable et al. (2003) revised the model of DeLone and McLean (1992) and reformulated their own model of information system success in an ERP context. 


\subsubsection{Gable et al.'s model (2003)}

Gable et al. (2003) were among the first authors to specify the dimensions of information system success in an ERP context. Why precisely the ERP context? An ERP system is different from other information technologies (Davenport, 2000). Its implementation takes into account the technological, operational, managerial, strategic and organizational components (Markus and Tanis, 2000; $\mathrm{Yu}, 2005)$. Accordingly, Gable et al. (2003) developed a model that redefines the dimensions used in the original model of DeLone and McLean (1992). In fact, they eliminated the use and user satisfaction dimensions in their model. The dimensions retained are thus information quality, ERP system quality, individual impact and organizational impact.

However, DeLone and McLean's (1992) and Gable et al. (2003) models ignore contextual influences (Ifinedo, 2006). Delone and McLean (1992) acknowledged this limitation. They recommended focusing not only on information system success dimensions, but on providing the external factors influencing this success. They added that a deeper understanding of information system success may emerge when external factors are considered in duality with the dimensions of success.

For this reason, our framework will take into account some factors that influence the success of the accounting information system. The choice of these factors has its roots in contingency theory.

\subsection{Contingency theory}

Since its inception, contingency theory has proposed that organizational effectiveness results from the association between organizational characteristics and contingency factors. A literature review identified that some previous research has focused its interest on the study of organizational variables as contingent factors that may influence accounting information systems.

Several researchers, such as Holmes and Nichols (1988), Chapellier (1994), Lavigne (2002), and Stepniewski et al. (2008), have identified a significant relationship between contingency factors, the complexity of the accounting information system and business performance. 
Choe (1998) argued that the design of an accounting information system can be influenced by contingent variables. These variables are classified into two groups: organizational variables and individual variables. The organizational variables are related to the organizational structure (Chenhall and Morris, 1986; Gerdin, 2005), the task uncertainty (Chong, 1996), the organizational strategy (Naranjo-Gil, 2004) and the budgetary participation (Tsui, 2001). The individual variables refer to the factors related to some individual characteristics that may have effects on accounting information systems.

The literature review identified the studies by Chapellier (1994), Lavigne (2002) and Ngongang (2007), who selected factors relating to the training, level of education, experience and age of the leader. These factors have significant effects on accounting information systems.

Contingency theory also proposes that organizational performance improves as a result of the interaction between organizational structure and context. In this context, a greater level of fit between the context and the structure leads to better organizational performance (Al-Omiri and Drury, 2007). Some studies opt for this view, which tests the interaction between the contingency factors, the accounting information system and the performance (Chong, 1996; Naranjo-Gil, 2004; Boulianne, 2007). These studies suggest that there is an interaction between the accounting information system and the factors that influence it. This assumes, however, that these factors are not independent of each other. Companies must allocate their resources in order to facilitate this interaction.

In this study, we will examine the role of certain factors that influence the accounting information system. These are the managers and computer external experts. We will also study the interaction effect between a contingency factor and the information system according to a moderation approach. According to Donaldson (2001), each variable that moderates the effect of organizational characteristics on organizational performance is considered as a contingency. He added that the contingency approach assumes that the effect of one variable on another depends on a third contingent variable. In this paper, we consider the accounting staff competency as the contingency that moderates the relationship between the accounting information system in an ERP context and the business performance. 


\section{HYPOTHESIS DEVELOPMENT}

\subsection{Relations between the AIS characteristics in an ERP environment}

A literature review allowed us to observe that the characterization of AISs in an ERP context can be made according to the accounting literature and the information systems literature. In the accounting literature, Chapellier (1994) characterized AISs by their accounting and management control practices, by financial analysis and by the balanced scorecard.

In the information systems literature, Chenhall and Morris (1986), Gul (1991), Tsui (2001) and Naranjo-Gil (2004) characterized AISs according to the information characteristics generated by these information systems, namely the scope, timeliness, aggregation and integration of information.

In addition, Gable et al. (2003) and Saeed and Abdinnour-Helm (2008) stated that system quality and information quality are two major characteristics of information systems.

We propose, therefore, to characterize the AIS in an ERP environment by combining the accounting literature with the information systems literature. We argue that this information system is characterized by the accounting practices used, by the information quality and by the ERP system quality.

\section{a. Accounting practices used}

The introduction of ERP technology has fundamentally changed the accounting practices either at the financial reporting and management accounting level or at the auditing techniques and tax level (Scapens and Jazaeyri, 2003). Spathis and Constatinides (2004) argued that a significant proportion of ERP adopters have introduced sophisticated accounting techniques, such the ABC method, financial ratios analysis, budgeting, profit centres and profitability analysis by the customer. Galani (2010) found that using the ABC method, targeted cost and balanced scorecard is greater in companies that have implemented an ERP.

Thus, AISs offer the potential application of general accounting practices, financial management practices and management control practices. 


\section{b. Information quality}

Several authors have characterized AISs by some modern attributes of the accounting information produced by these information systems. These characteristics are information scope, timeliness, level of aggregation and integration (Gul, 1991; Mia, 1993; Mia and Chenhall, 1994; Tsui, 2001). In this sense, Gul (1991) and Mia (1993) suggested that accounting information systems should not be limited to a traditional orientation (information that is historical and quantified in monetary terms and information oriented to outside the company). Instead, they should have a broader scope.

Such a system should include non-financial measures of the environmental characteristics of the company. It must, however, provide forecasts of the likelihood of future events. In addition, an accounting information system should provide relevant information in real time and should frequently report on the most important events and provide rapid feedback on the previous technology.

\section{c. ERP system quality}

Guvence (2005) defined system quality as the technical characteristics of the information system. According to Zhang et al. (2005), the ERP system quality consists of its flexibility, ease of use, reliability, short response time and useful specific functions. Ifinedo and Nahar (2007) presented the characteristics of flexibility, ease of use, ease of learning and integration to define the quality of the ERP system.

\subsubsection{Impact of information quality on the accounting practices used}

Kanellou and Spathis (2011) confirmed that there is a reduction in the time and frequency of preparation of financial statements (monthly, quarterly and annual financial statements) after the adoption of an ERP. Similarly, Salehi et al. (2010) confirmed in their study that a sophisticated AIS improves accounting performance. This performance is reflected in the adoption of new accounting techniques. Rom (2008) concluded, then, that ERP systems are considered an important source of information for most accounting practices.

Al-Eqab and Ismail (2011) demonstrated that extended, timely, frequent, aggregated and integrated accounting information should be particularly useful for managers to enable them to respond quickly to changing environmental and market demands. Based on this information, officers will request the use of more 
advanced accounting practices. In this sense, Galani et al. (2010) showed that the more the information that results from an ERP system is of greater quality, the more it provides support for leaders to establish strategic and operational budgets.

In light of these works, we propose:

H1: The quality of information derived from the AIS has an effect on the accounting practices used.

\subsubsection{Impact of ERP system quality on the accounting practices used}

The evolutions experienced in information systems have caused them to play a facilitating role in the introduction of accounting techniques (Rom, 2008). Indeed, Granlund (2001) identified that the establishment of an advanced information technology would introduce a change in management accounting practices. In the particular case of ERP systems, the latter is considered an important source of new accounting practices (Booth et al, 2000).

In his study, Rom (2008) proposed to focus on the technical aspects of ERPs and examine their impact on management accounting practices. In fact, Rom (2008) defined the technical support of an ERP system as the ability of all its technical characteristics to design and consequently to use management accounting practices.

We then propose:

H2: ERP system quality has an effect on the accounting practices used.

\subsection{Impacts of contingency factors on the accounting information system}

\subsubsection{Impacts of external expertise quality on the AIS}

\subsubsection{External expertise quality and information quality}

External expertise refers to external mediators' entities, such as the ERP vendors and IT consultants who provide the knowledge, training, maintenance and other technical support for companies that have implemented ERP systems (Ifinedo, 2008).

Wang and Chen (2006) argued that these consultants are actively involved in the stages of ERP system implementation by transferring a large amount of 
information and translating the organizational requirements into the system configuration. Ifinedo (2008) confirmed that the quality of external expertise influences the quality of the information generated by the information system. Particularly in the context of AISs, the advice of external experts could provide high-quality information and result in an effective accounting information system (Ismail, 2009).

We thus propose the following hypothesis:

H3: The quality of external expertise has an effect on the quality of the information issued by the AIS.

\subsubsection{External expertise quality and ERP system quality}

The system provider is an important factor in the establishment and maintenance of a quality system (Wang et al, 2008). The support comes mainly from the insurance of technical assistance and urgent maintenance, frequent updates and reliable service (Zhang et al, 2005; Ramayah et al, 2007). Thus, good external expertise would enable companies to strengthen the use of complex systems such as ERP and achieve their organizational objectives (Sedera et al, 2003; Ko et al, 2005).

Ifinedo (2006) showed in a study of seven cases of companies in Finland and Estonia that users obtain the best benefits from their ERP system when they are assisted by consultants or suppliers who have communication skills and provide quality training programmes. Wang and Chen (2006) and Ifinedo (2008) also confirmed that the quality of external expertise influences the quality of the ERP system. Moreover, Ismail (2009) demonstrated that external experts contribute to the greater technical quality of the system.

We, then, propose the following hypothesis:

H4: The quality of external expertise has an effect on ERP system quality.

\subsubsection{3 . External expertise quality and the accounting practices used}

Sulaiman et al. (2008) argued that the external expert is a key agent in driving change in the use of new accounting practices. In addition, Moalla (2006) considered the external expert as a change agent. He or she may therefore play an important role in the adoption of accounting techniques. 
Benefiting from the knowledge, understanding and persuasiveness of these channels, companies can implement this new accounting technique. IT consultants and ERP vendors can be considered as interpersonal channels to provide clarification and additional information on the ERP system and thus facilitate the introduction of new accounting practices. We expect, then, that their effect is important in the adoption of these practices following the implementation of the ERP system. Hence, we propose the following hypothesis:

H5: The quality of external expertise has an effect on the accounting practices used.

\subsubsection{Impacts of top management commitment to the AIS}

\subsubsection{Top management commitment and information quality}

In his thesis, $\mathrm{Xu}$ (2003) showed that top management commitment is the most important factor among 25 factors in determining the quality of accounting information. In this sense, if a company aspires to have good accounting information, it is necessary for managers to have the initiative to ensure that quality.

Ismail and King (2007) showed that poor understanding of accounting information by managers deprives companies of an AIS that is able to align the information requirements with its technical capacity. In turn, Al-Eqab and Ismail (2011) confirmed the hypothesis that top management commitment has a significant effect on accounting information quality. They argued that this commitment is crucial to the success of the AIS. An executive with great knowledge of information technology is more able to understand the design of the AIS. He exploits his knowledge during the information system development in order to meet the information needs. So, we propose:

H6: Top management commitment to the ERP implementation project has an effect on the quality of the information issued by the AIS.

\subsubsection{Top management commitment and ERP system quality}

Guimaraes et al. (2003) and Sabherwal et al. (2006) confirmed that user involvement in the information system implementation has a significant effect on the system quality, concluding that the participation of the manager in initiating 
the project and in defining its objectives can lead to a high-quality system. De Guinea et al. (2005) showed that top management commitment is positively correlated with the ease of use of the AIS. In the context of ERP, Wang and Chen (2006) showed that top management commitment participates indirectly in ERP system quality via its positive influence on conflict resolution during the implementation process. Hence, we put forward the following hypothesis:

H7: Top management commitment to the ERP implementation project has an effect on the ERP system quality.

\subsubsection{Top management commitment and the accounting practices used}

The top manager is well placed to align the accounting information system with the information needs of the organization by formulating these needs in the form of accounting practices (Al-Eqab and Ismail, 2011). In fact, by participating in defining the information needs during the ERP implementation, the executive will require informational preferences from his new accounting information system. These preferences will affect the amount of accounting information produced. The leader will request more extensive information to satisfy his business needs. In this context, Lavigne (1999) identified a link between accounting practices and the executive informational preferences of SMEs. Thus, we formulate the following hypothesis:

H8: Top management commitment to the ERP implementation project has an effect on the accounting practices used.

\subsection{Impacts of the accounting information system on firm performance}

\subsubsection{Impacts of the accounting practices used on firm performance}

Ngongang (2005) validated that there is a statistically significant relationship between accounting practices and performance expressed in terms of autonomy, turnover evolution and reduced cost levels. In addition, and in a context of advanced information technologies, Rom (2008) proposed that these technologies influence the business processes, which in turn influence the business performance. These processes will be represented by the accounting practices adopted by firms after the implementation of an ERP. 
In this sense, information technology would change the adoption strategy of accounting practices, which could lead to better performance. The same author stated that the performance could be assessed by the degree to which accounting techniques would be facilitators of performance.

Accordingly, we propose:

H9: The accounting practices used after the adoption of an ERP system have an effect on the firm performance.

\subsubsection{Impacts of information quality on firm performance}

Wang (2003) stated that the provision of extensive information by an AIS encourages leaders operating under conditions of intense competition to request this information and to use it to increase further the chances of success of their organizations. In addition, fast and frequent information helps executives make appropriate decisions, seize profitable opportunities and improve their firm performance.

In their studies, Gul (1991), Mia (1993) and Ni et al. (2007) supported the hypothesis that postulates that extensive, forecasting, external, non-financial, fast and frequent information contributes to the performance of companies operating in a competitive and unpredictable environment. In the context of ERP, Doms et al. (2004) proposed that when a company implements this system, the information derived from it is relevant to users. This would lead to greater organizational effectiveness.

For their part, Hendricks et al. (2007) argued that the reports prepared by the ERP system allow managers to have a clearer vision of the performance of each department of the company. These reports can therefore be used to identify the improvements needed and take advantage of market opportunities.

Hence, the following hypothesis is presented:

H10: The quality of the information issued by the AIS has an effect on firm performance. 


\subsubsection{Impacts of ERP system quality on firm performance}

Jiwat and Malcom (2009) predicted the existence of an effect of system quality on firm performance. Maldonado (2009) verified that the ease of use, considered as one dimension of the ERP system quality, has a significant effect on improving performance. Velcu (2007) also showed that the perceptions of users regarding the usability of ERP are crucial when the ERP system starts to generate profits.

Hence, we formulate the following hypothesis:

H11: ERP system quality has an effect on firm performance.

\subsection{Interaction between AIS, accounting staff competency and firm performance}

The study of the interaction effect between the AIS, the accounting staff competency and the firm performance will be conducted using a moderation approach. We consider the accounting staff competency as the moderator that will act in the relationship between AIS characteristics and company performance. In fact, the ability of the characteristics of an accounting information system to explain business performance depends on the level of accounting staff competency.

The competency of accounting personnel is an important factor in the success of the accounting information system. These members of staff are called upon to accomplish various tasks regarding the accounting, finance and information system of the organization. In the context of ERP, an accountant must demonstrate an ability to work in groups because the information is shared in real time. He must master the tool and adapt to change. He must have an understanding of all the system and interactions. Such skills enable these professionals to control the functioning of the AIS (Caglio, 2003) and add value to their companies (Ismail, 2009). Moreover, Ismail and King (2007) proposed that the existence of qualified accounting staff could help companies and executives to equate the importance of the accounting information in managing their financial performance. Then, we consider that the role of the accounting staff in the use of accounting practices could be a facilitator of the performance of accounting information system. The latter will, therefore, have a greater impact on business performance (Figure 2). Hence, 
H12: The relationship between AIS and business performance is moderated by the competency of accounting personnel; companies are more efficient with competent accounting staff.

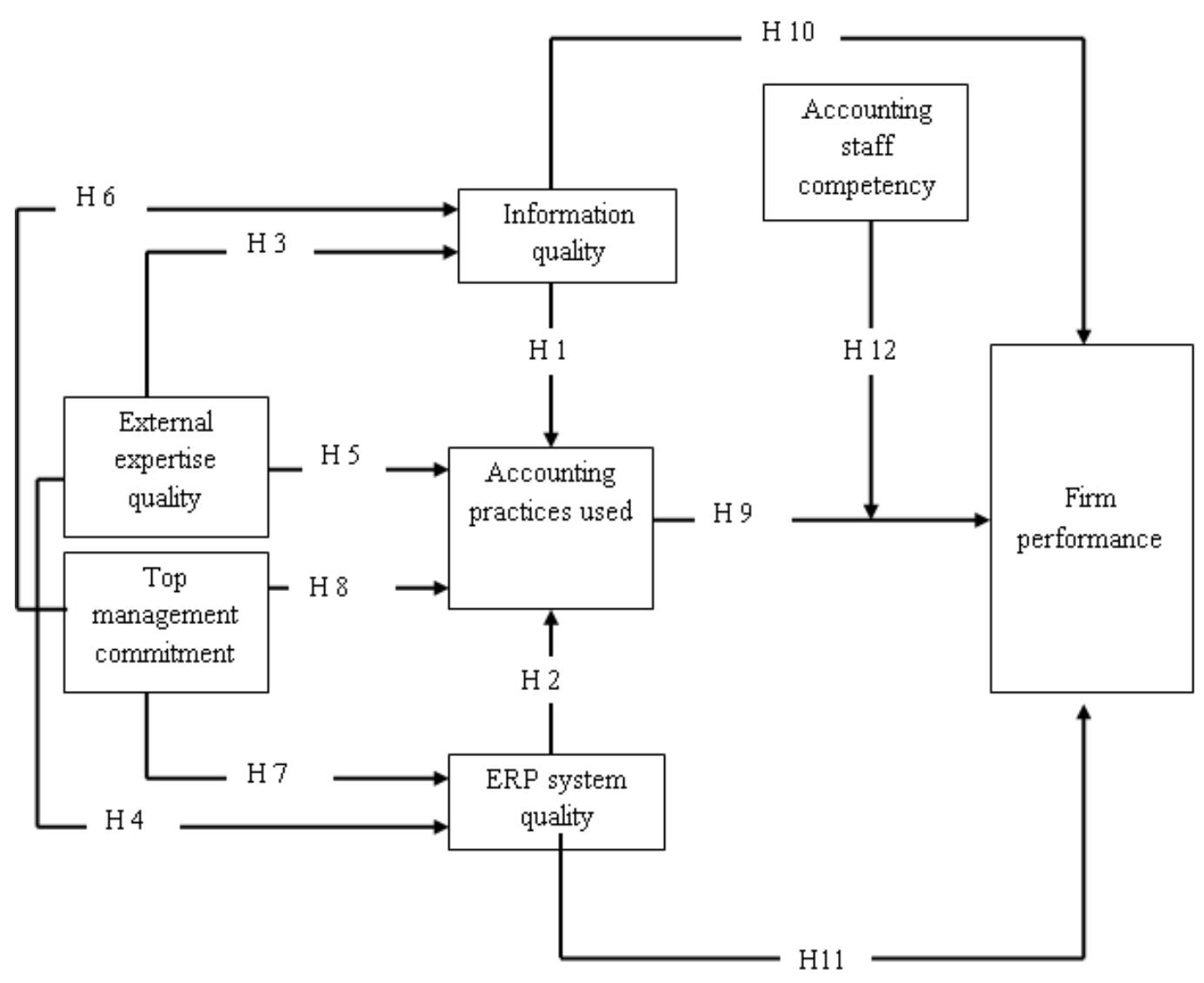

Figure 2: Conceptual research model

\section{RESEARCH METHODOLOGY}

\subsection{Data collection}

A survey was carried out in Tunisian companies that have implemented an ERP system. A total of 195 companies were targeted from the identification of these companies by consulting the sites of some ERP vendors on the Internet. The unit of analysis of this study is the organization; it was ensured that key actors of the company participated in the study. These were the managing directors, executive 
and financial directors, management controllers, chief accountants and accountants. These groups of respondents are considered to be the most qualified to tell us about some performance indicators of their businesses.

In total, 110 questionnaires were returned (with an effective response rate of $56.4 \%$ ). However, usable responses accounted for only 102 questionnaires; 8 questionnaires were not admitted to the study as they were returned incomplete. The respondents' profiles are shown in table 1.

\begin{tabular}{|l|c|c|}
\hline Respondents' characteristics & Frequency & Percentage \\
\hline Gender & 78 & 76.5 \\
Male & 24 & 23.5 \\
Female & 18 & \\
\hline Age & 50 & 17.6 \\
Between 20 and 29 & 26 & 25.5 \\
Between 30 and 39 & 8 & 7.8 \\
Between 40 and 49 & & \\
More than 50 & 44 & 43.1 \\
\hline Education & 52 & 51 \\
Third cycle & 2 & 2 \\
Master & 3 & 2.9 \\
Diploma of first cycle & 1 & 1 \\
Baccalaureate & & \\
Less than baccalaureate & 8 & 7.8 \\
\hline Function & 24 & 23.5 \\
Managing director & 8 & 7.8 \\
Executive and financial director & 31 & 30.4 \\
Management controller & 14 & 13.7 \\
Chief accountant & 17 & 16.7 \\
Accountant & & \\
Other & & \\
\hline
\end{tabular}

Table 1: Respondents' profiles

\subsection{Data analysis}

The partial least squares (PLS) technique of structural equation modelling was used for data analysis. PLS is suitable for small sample sizes such as this one. The specific tool used was SmartPLS 2.0 of Ringle et al. (2005).

Before applying the PLS technique, exploratory factor analysis must be performed on the different variables of the research. Principal component analysis is conducted in this step by means of SPSS 18.0 (table 2). 


\begin{tabular}{|c|c|c|c|c|c|c|c|c|c|}
\hline Items & P1 & $\begin{array}{l}\mathbf{P 2} \\
\end{array}$ & Q1 & $\mathbf{Q 2}$ & $\mathrm{QS}$ & $\mathbf{Q E}$ & ED & $\mathrm{CC}$ & PER \\
\hline PC1 & 0.809 & & & & & & & & \\
\hline PC2 & 0.853 & & & & & & & & \\
\hline PC3 & 0.800 & & & & & & & & \\
\hline PC4 & 0.703 & & & & & & & & \\
\hline PC8 & & 0.801 & & & & & & & \\
\hline PC9 & & 0.829 & & & & & & & \\
\hline QI1 & & & 0.939 & & & & & & \\
\hline QI2 & & & 0.903 & & & & & & \\
\hline QI3 & & & 0.922 & & & & & & \\
\hline QI4 & & & 0.907 & & & & & & \\
\hline QI5 & & & 0.846 & & & & & & \\
\hline QI6 & & & & 0.795 & & & & & \\
\hline QI7 & & & & 0.785 & & & & & \\
\hline QS1 & & & & & 0.869 & & & & \\
\hline QS2 & & & & & 0.771 & & & & \\
\hline QS4 & & & & & 0.807 & & & & \\
\hline QE1 & & & & & & 0.674 & & & \\
\hline QE2 & & & & & & 0.703 & & & \\
\hline QE3 & & & & & & 0.796 & & & \\
\hline QE4 & & & & & & 0.763 & & & \\
\hline QE5 & & & & & & 0.839 & & & \\
\hline ED1 & & & & & & & 0.723 & & \\
\hline ED2 & & & & & & & 0.823 & & \\
\hline ED3 & & & & & & & 0.822 & & \\
\hline ED4 & & & & & & & 0.783 & & \\
\hline ED5 & & & & & & & 0.798 & & \\
\hline $\mathrm{CC} 1$ & & & & & & & & 0.810 & \\
\hline $\mathrm{CC} 2$ & & & & & & & & 0.880 & \\
\hline $\mathrm{CC} 3$ & & & & & & & & 0.814 & \\
\hline PER2 & & & & & & & & & 0.726 \\
\hline PER3 & & & & & & & & & 0.809 \\
\hline PER4 & & & & & & & & & 0.795 \\
\hline Eigenvalue & 3.035 & 1.316 & 4.116 & 1.572 & 2 & 2.869 & 3.11 & 2.094 & 1.815 \\
\hline
\end{tabular}

Table 2: Principal component analysis

The results of the exploratory factor analysis show a structure of nine factors with eigenvalues $>1$. These results indicate that the measurement scales are onedimensional scales, with the exception of the "accounting practices" and "information quality" variables, which prove to be bi-dimensional.

\subsubsection{First-order confirmatory analysis}

In this step, we will evaluate the internal consistency, convergent validity and discriminant validity of the model. 
Internal consistency is ensured when the reliability of each measurement is > 0.7 (Nunally, 1978). Reliability is assessed by Cronbach's alpha and composite reliability.

All the research variables have a Cronbach's alpha and composite reliabilities with acceptable values to support adequate internal consistency of the study's data. Convergent validity is assured when each construct has an average variance extracted (AVE) of at least 0.5 (Fornell and Larcker, 1981).

Discriminant validity is assured when: (a) each item has an item loading greater than 0.6 on its respective constructs (Hair et al, 1998) and (b) the square root of all the constructs is larger than all the other AVE cross-correlations, and no item loads highly on any other construct(s). The results show that the AVEs range from 0.56 to 0.83 . Convergent validity is thus demonstrated. The results also indicate that the values on the diagonal are much higher than any other value in the lower part to the diagonal, confirming discriminant validity. It is also apparent that the items are highly correlated with their corresponding construct and weakly correlated with the other constructs. This asserts the discriminant validity of the measurement scales (Table 3).

\begin{tabular}{|l|c|c|c|c|}
\hline \multirow{2}{*}{ Research variables } & Factor & $\begin{array}{c}\text { Cronbach's } \\
\text { alpha }\end{array}$ & $\begin{array}{c}\text { Composite } \\
\text { reliability }\end{array}$ & AVE \\
\hline Accounting practices & P1 & 0.83 & 0.88 & 0.67 \\
\cline { 2 - 5 } & P2 & 0.79 & 0.91 & 0.83 \\
\hline \multirow{2}{*}{ Information quality } & Q1 & 0.94 & 0.95 & 0.81 \\
\cline { 2 - 5 } & Q2 & 0.73 & 0.88 & 0.78 \\
\hline ERP system quality & QS & 0.75 & 0.85 & 0.66 \\
\hline External expertise quality & QE & 0.81 & 0.86 & 0.56 \\
\hline Top management commitment & ED & 0.85 & 0.89 & 0.62 \\
\hline Accounting staff competency & CC & 0.78 & 0.86 & 0.67 \\
\hline Firm performance & PER & 0.67 & 0.81 & 0.60 \\
\hline
\end{tabular}

Table 3: First-order confirmatory analysis 


\subsubsection{Second-order confirmatory analysis}

This analysis ensures that the dimensions identified in the first order represent well a broader and more abstract construct. The contributions of each factor dimension as far as second-order constructs are concerned must be $>0.7$ (Hensler et al, 2009).

The second-order confirmatory analysis is here applied to the variables "accounting practices" and "information quality", which are two-dimensional. It should thus ensure that the factors identified in these two variables are secondorder constructs.

\begin{tabular}{|c|c|c|c|}
\hline & Factor & Loading factor & t-test \\
\hline \multirow{2}{*}{$\mathrm{PC}(\alpha=0.82 ; \mathrm{CR}=0.85 ; \mathrm{AVE}=0.505)$} & $\mathrm{P} 1$ & 0.926 & 65.294 \\
\cline { 2 - 4 } & $\mathrm{P} 2$ & 0.686 & 8.780 \\
\hline \multirow{2}{*}{$\mathrm{QI}(\alpha=0.84 ; \mathrm{CR}=0.89 ; \mathrm{AVE}=0.58)$} & $\mathrm{Q} 1$ & 0.981 & 69.592 \\
\cline { 2 - 4 } & $\mathrm{Q} 2$ & 0.285 & 2.428 \\
\hline
\end{tabular}

Table 4: Second-order confirmatory analysis

From this table, we find that the $\mathrm{P} 1$ and $\mathrm{P} 2$ factors contribute to the formation of the accounting practices construct. The latter is still reliable and its convergent validity is satisfied. However, only the factor Q1 contributes to the formation of the information quality construct. The factor Q2 will, therefore, be eliminated from the analysis.

\subsubsection{Hypotheses testing}

With regard to the assessment of the structural model, information about the squared R (R2) and the path coefficients $(\beta)$ is provided. The hypotheses were tested by following Chin's (1998) guidelines. He recommended that the path significance can be estimated through t-test values using the bootstrapping procedure (with 500 subsamples). The SmartPLS 2.0 results for the $\beta$ s and the R2 are shown in Figure 3.

Most of the hypotheses were confirmed ( 9 of 12 hypotheses are supported). Three hypotheses were rejected. Hypothesis H3, which predicted that external expertise quality has an effect on information quality, was invalidated by the 
research $(\beta=-0.092)$. Hypotheses H10 and H11 were not confirmed. Information quality $(\beta=-0.08)$ and ERP system quality $(\beta=-0.024)$ had no influence on firm performance.

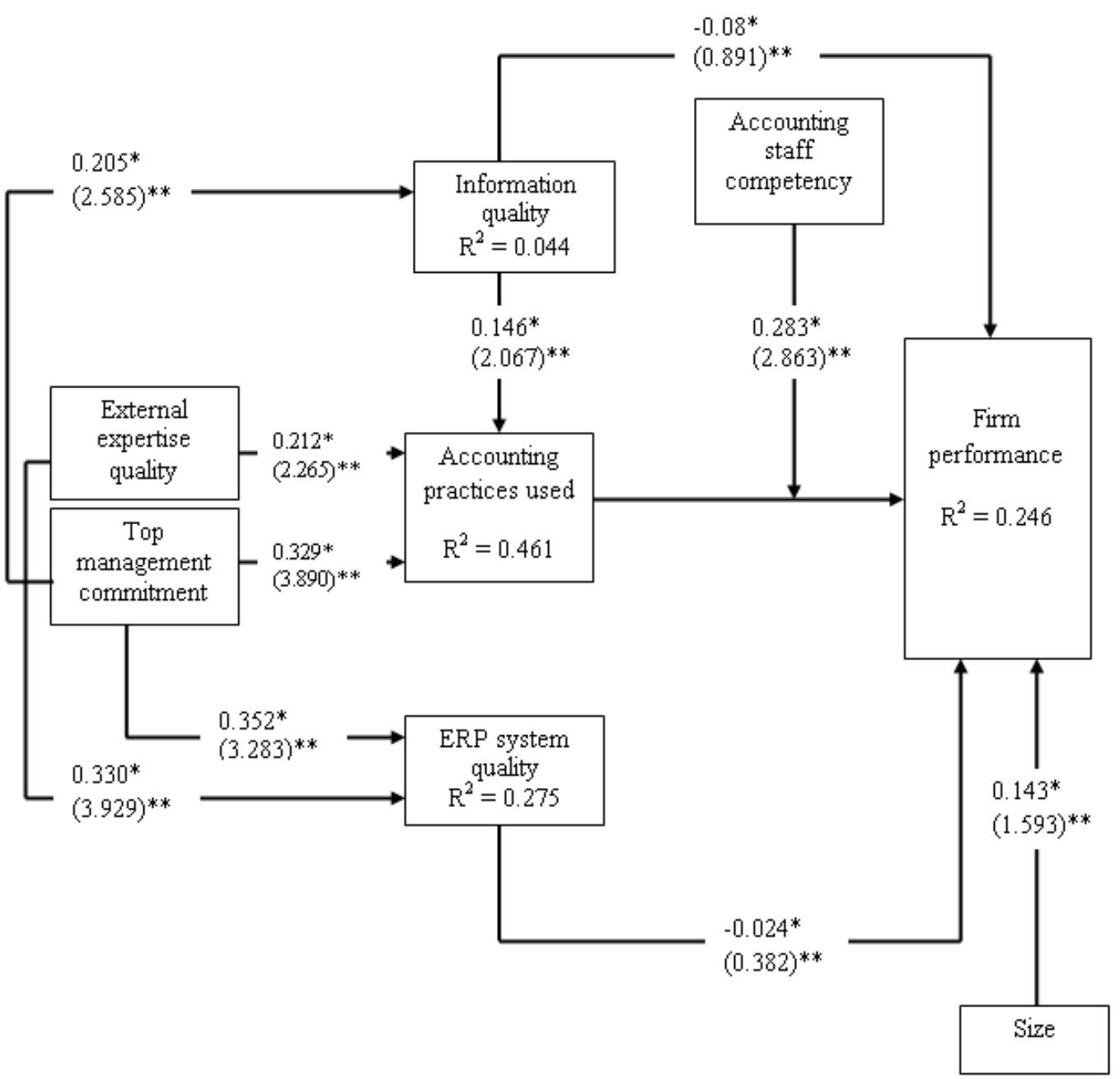

*corresponds to path coefficient $\beta$

** corresponds to t-test

Figure 3: The Smart PLS 2.0 results for the tested relationships

Confirming hypotheses $\mathrm{H} 1$ and $\mathrm{H} 2$, we can conclude that information quality ( $\beta=0.146)$ and ERP system quality $(\beta=0.320)$ had a significant effect on the accounting practices used. 
The study also confirms hypotheses H4 and H5. These assumptions suggest that external expertise quality influences ERP system quality $(\beta=0.332)$ and the accounting practices used $(\beta=0.212)$.

The results also show acceptance of hypotheses H6, H7 and H8. These hypotheses confirm that top management commitment has a statistically significant effect on information quality $(\beta=0.205)$, on ERP system quality ( $\beta=$ $0.352)$ and on the accounting practices used $(\beta=0.329)$. Hypothesis $H 9$, which was formulated to examine the relationship between accounting practices and firm performance, is also confirmed $(\beta=0.309)$.

Finally, and by adopting a moderation approach, we tested with hypothesis H12 the interaction effect of accounting staff competency with the accounting practices and tested their impact on improving firm performance. To achieve this purpose, we constructed a multiplicative variable representing the interaction effect between accounting practices and accounting staff competency. Two equations were then tested:

$$
\text { Equation (1): PER }=a+\beta 1 E F F+\beta 2 P C+\beta 3 C C
$$

Equation (2): $P E R=a+\beta 1 E F F+\beta 2 P C+\beta 3 C C+\beta 4(P C * C C)$

where: PER is the firm performance

EFF is the company size

$\mathrm{PC}$ is the accounting practices used

$\mathrm{CC}$ is the accounting staff competency

$\mathrm{PC} * \mathrm{CC}$ is the interaction term between accounting practices and accounting staff competency.

We note that the structural coefficient $\beta 4$ of the variable interaction is significant at the $1 \%$ level and the R2 of the second equation is higher than the first. These results show that the accounting staff competency plays a moderating role in the relationship between accounting practices and performance. These observations allow us to accept H12 (Table 5). 


\begin{tabular}{|c|c|c|c|}
\hline Equations estimated & $\beta$ & t-Student & $\overline{\mathrm{R}^{2}}$ \\
\hline \multirow{3}{*}{ Equation (1) } & $\beta 1=0.140$ & 1.598 & \multirow{3}{*}{0.188} \\
\hline & $\beta 2=0.298$ & $2.170 * *$ & \\
\hline & $\beta 3=0.175$ & $1.68 * * *$ & \\
\hline \multirow{4}{*}{ Equation (2) } & $\beta 1=0.143$ & 1.593 & \multirow{4}{*}{0.246} \\
\hline & $\beta 2=0.309$ & $2.292 * *$ & \\
\hline & $\beta 3=0.186$ & $1.925 * * *$ & \\
\hline & $\beta 4=0.283$ & $2.863^{*}$ & \\
\hline
\end{tabular}

Table 5: Moderation effect results

\section{DISCUSSIONS}

The objective of this paper was to test empirically the influence of accounting information systems on business performance. The research model has an explanation percentage of the performance of $24.6 \%$. This rate is considered to be moderate according to Cohen's categorization (1988).

Hypothesis $\mathrm{H} 1$ confirmed that information quality influences accounting practices, in accordance with Booth et al. (2000), Granlund and Malmi (2002), Galani et al. (2010) and Kanellou and Spathis (2011). One possible explanation for this result proposes that the extended information provided by the AIS would allow companies to diversify their use of accounting practices. Companies will use general accounting practices, cost accounting and financial management in response to the new requirements of the AIS that are producing fast, accurate, frequent, analytical, predictive and forward-thinking company information.

Hypothesis $\mathrm{H} 2$ confirmed a positive relationship between ERP system quality and accounting practices, in accordance with Granlund (2001) and Rom (2008). This result means that ERP system quality supports the use of "new" accounting practices. Indeed, a system that responds quickly to user requirements and that is easy to use would facilitate the use of advanced accounting practices, such as holding a balanced scorecard, budgeting, profitability analysis, etc.

Concerning the effect of external expertise quality on the different features of the AIS, the contribution of this variable has not been demonstrated in relation to 
information quality (H3). We conclude, therefore, that even if the external expert is qualified, it does not help to have extended, fast and frequent information. Information quality remains the concern of the internal commitment to the company that knows the best attributes of accounting information. This result differs from the work of Wang and Chen (2006) and Ismail (2009).

However, external expertise has an effect on system quality (H4) and on the accounting practices used (H5). In fact, the credibility of and trust in the ERP provider and the quality of its service and quality of support provided would result in an ERP system of high quality. Businesses will therefore have the support of the external expert compensating for their inability to understand the operation of the software. Thus, firms attach more importance to external resources expertise that can provide the knowledge and support required in order to make the best use of their ERP systems. The studies by Ifinedo (2006), Wang and Chen (2006) and Ismail (2009) confirm this result.

Furthermore, the ERP vendor or consultant would help businesses increase their use of accounting practices following the implementation of the ERP system. Companies benefit from the knowledge and expertise of these agents to facilitate the introduction of these practices. This result corroborates those found by Sulaiman et al. (2008).

Regarding the effect of contingency factors on the internal reporting system, it was demonstrated that top management commitment affects information quality (H6) in line with Xu (2003) and Al-Eqab and Ismail (2011), affects system quality (H7) in accordance with De Guinea (2005) and affects the accounting practices used (H8) in accordance with Al-Eqab and Ismail (2011). These results allow us to conclude that top management commitment influences the accounting information systems at the information quality level, at the system quality level and at the accounting practices level. In this sense, not only would a manager involved in the implementation project of the ERP system allow the accounting information system to generate financial and backward-looking company information, but also the contribution of such a commitment would permit the production of predictive, non-financial and non-economic information. This commitment would also facilitate a system that is easy to use, which delivers compatible functionality with user requests. We affirm, though, that the top 
management commitment to defining information needs, selection, implementation and maintenance of the ERP system and its involvement in problem solving and the deployment of future use of information technologies allow companies to adopt financial accounting and management accounting practices and financial management.

Moreover, we show in our research that the characteristics of AISs influence performance. However, only accounting practices are demonstrated to influence business performance, allowing us to conclude that after the adoption of an ERP system, companies use "new" accounting techniques such as holding a balanced scorecard, budgeting and financial analysis of profitability. These techniques would influence the growth of sales, customer loyalty and availability of financial resources.

Our study was unable to establish a relationship between on the one hand information quality (H10) and the other system quality (H11) and firm performance. We interpret the rejection of hypotheses $\mathrm{H} 10$ and $\mathrm{H} 11$ by the fact that theoretically and specifically, in the DeLone and McLean model (1992), information quality and system quality are not directly linked to organizational performance. These dimensions affect performance indirectly through other variables of success of the information system (such as user satisfaction and individual performance).

In hypothesis H12, we verify that the performance would be influenced by the accounting staff competency. This variable is assumed to interact with accounting practices. We conclude that the more accounting personnel have technical skills and experience in carrying out their tasks, the more companies are using advanced accounting practices and the better they will be performing.

\section{CONCLUSIONS, LIMITATIONS AND FUTURE RESEARCH}

We aimed in this research to determine how and to what extent the implementation of an accounting information system in an ERP context influences corporate performance. Our goal was to study the direct and interaction effects that exist between accounting information systems, contingency factors and business performance. We, thus, used the PLS approach to test these relations. The results obtained show that business performance is influenced mainly by the new accounting practices used after the ERP adoption. 
Firm performance improves when firms have competent accounting staff. The results also show that accounting practices are determined by top management commitment to the ERP system deployment project and by qualified external expertise. These practices are also influenced by the information quality produced by the accounting information system and by the ERP system quality. However, information quality and ERP system quality do not have a significant effect on firm performance.

Our work contributes to scientific research on theoretical and practical levels. On a theoretical level, our work represents an attempt to explain corporate performance by the accounting information system. To our knowledge, few studies have addressed accounting information systems in the ERP context. Our contribution at this level is manifested by the introduction of accounting practices as a characteristic of the AIS to the information system success model of Delone and McLean (1992).

In addition, our paper contributes by testing a moderating effect exerted by the accounting staff competency. To our knowledge, no studies have tested the joint effect of this variable on the accounting information system and corporate performance. On the managerial level, our work confirms the importance of top management commitment and external expertise in determining accounting information systems. Managers must thus be aware of the importance of promoting and supporting the adoption of new technologies to succeed in accounting information systems. Moreover, companies must hire a qualified external expert who possesses experience and technical knowledge. This partner would allow the company to overcome the deficiencies of the AIS. Companies can therefore improve their knowledge of this information system and ensure its success.

Furthermore, this research confirms that the ERP system allows the use of new general accounting practices, cost accounting and financial management. Companies must strive to increase their use of these practices to improve their performance. In addition, they must consider that the use of these practices is greater when they recruit competent accounting personnel. Companies must then pay particular attention to their accounting department personnel, who will 
participate in achieving the performance objective by promoting their skills by providing training sessions on the new information systems.

Despite its contributions, this study presents some limitations. The first limitation concerns the sample bias, which may affect the generalizability of the results. Our sample was selected according to the empirical method, which consists of building the sample through a rational choice of individuals to investigate because we did not have an exhaustive list of companies with an ERP system.

The second limitation concerns the small sample size. A larger sample would increase the statistical validity and improve the generalizability of the results. The data are obtained from a questionnaire sent to respondents belonging to large companies. These responses were not easily obtainable.

The third limitation concerns measurement scales. This study is based on subjective measures provided by respondents' perceptions. This approach may cause some bias. However, the use of perceptions was considered appropriate for this research because most of the data required to evaluate the research variables are intangible in nature and it would be difficult, if not impossible, to collect them objectively.

Taking into account these limitations, we can offer directions for future research. Future studies could explore the contribution of other contingency factors that may influence the AIS, such as the external accountant and internal auditor. We may also consider improving the moderating effect of the accounting staff competency by developing a measuring instrument that addresses the new skills of staff in the context of modernized accounting information systems. A qualitative study could be considered for this purpose.

It would also be promising to assess the organizational impact of an accounting information system before and after the adoption of the ERP system. A longitudinal study would be possible to appreciate the evolving nature of AIS through time. Moreover, we can incorporate objective measures of performance into subjective measures to improve the validity of the results. 


\section{REFERENCES}

AFFES, H.; CHABCHOUB, A. (2007): "Le système d' information comptable: les déterminants de ses caractéristiques et son impact sur la performance financière des PME en Tunisie", La Revue des Sciences de Gestion: Direction et Gestion, vol. 42, n. 224/225: 59-70. http://dx.doi.org/10.1051/larsg:2007018

AL-EQAB, M.; ISMAIL, N.A. (2011): “Contingency factors and accounting information system design in Jordanian companies", IBIMA Business Review, vol. 11: 12. http://dx.doi.org/10.5171/2011.166128

AL-OMIRI, M.; DRURY, C. (2007): “A survey of factors influencing the choice of product costing systems in UK organizations", Management Accounting Research, vol. 18, n. 4: 399-424. http://dx.doi.org/10.1016/j.mar.2007.02.002

BALLANTINE, J.; LEVY, M.; POWELL, P. (1998), "Evaluating information systems in small and medium-sized enterprises: issues and evidence", European Journal of Information Systems, vol. 7, n. 4: 241-251. http://dx.doi.org/10.1057/p algrave.ejis. 3000307

BOOTH, P.; MATOLCSY, Z.; WIEDER, B. (2000): "The impacts of enterprise resource planning systems on accounting practice: the Australian experience", Australian Accounting Review, vol. 10, n. 3: 4-18. http://dx.doi.org/10.1111/j.183 5-2561.2000.tb00066.x

BOULIANNE, E. (2007): "Revisiting fit between AIS design and performance with the analyzer strategic-type", International Journal of Accounting Information Systems, vol. 8: 1-16. http://dx.doi.org/10.1016/j.accinf.2006.12.001

CAGLIO, A. (2003): "Enterprise Resource Planning Systems and Accountants: Towards Hybridization?" European Accounting Review, vol. 12, n.1: 2353.http://dx.doi.org/10.1080/0963818031000087853

CHAPELLIER, P. (1994): “Comptabilités et Système d'Information du Dirigeant de PME - Essai d'observation et d'interprétation des pratiques", $\mathrm{PhD}$ in Management Science, Montpellier II University.

CHAPELLIER, P.; MOHAMMED, A. (2010): “Le système d'information comptable des PME syriennes: Complexité et déterminants", paper presented at 
the 10th international Francophone congress in Entrepreneurship and SME, Bordeaux, France.

CHENHALL, R.H. (2003): "Management control systems design within organisational context: findings from contingency-based research and directions for the future", Accounting, Organisation and Society, vol. 28: 127-168. http://dx.doi.org/10.1108/18347641011023270

CHENHALL, R.H.; MORRIS, D. (1986): “The impact of structure, environment, and interdependence on the perceived usefulness of management accounting systems", Accounting Review, vol. 61, n. 1: 16-35.

CHIN, W. (1998): "Issues and opinion on structural equation modelling", MIS Quarterly, vol. 22, n.1: 7-15.

CHOE, J.M. (1998): "The effects of user participation on the design of accounting information systems", Information \& Management, vol. 34, n. 3: 185-198. http://dx.doi.org/10.1016/S0378-7206(98)00055-X

CHONG, V.K. (1996): "Management accounting systems, task uncertainty and managerial performance: a research note", Accounting, Organization and Society, vol. 21, n. 5: 415-421. http://dx.doi.org/10.1016/0361-3682(95)00045-3

COHEN, J. (1988): "Statistical power analysis for the behavioural sciences", 2nd ed., Lawrence Erlbaum Associates, Hillsdale, NJ.

DAVENPORT, T.H. (2000), "Mission critical: realizing the promise of enterprise systems", Harvard Business School Press, Boston.

DELONE, W.; MCLEAN, E. (1992): "Information system success: the quest for the dependent variable", Information Systems Research, vol. 3, n. 1: 60-95.

DELONE, W.; MCLEAN, E. (2003): “The DeLone McLean model of information system success: a ten-year update", Journal of Management Information Systems, vol. 19, n. 4: 3-9.

DE GUINEA, A.O.; KELLEY, H.; HUNTER, M.G. (2005): "Information systems effectiveness in small businesses: extending a Singaporean model in Canada", Journal of Global Information Management, vol. 13, n. 3: 25-55. http://dx.doi.org /10.4018/jgim.2005070104 
DOMS, M.E.; JARMIN, R.S.; KLIMEK, D.S. (2004): “Information technology investment and firm performance in U.S. retail trade", Economics of Innovation and New Technology, vol. 13, n. 7: 595-613. http://dx.doi.org/10.1080/104385904 $\underline{2000201911}$

DONALDSON, L. (2001): "The Contingency Theory of Organizations", Sage Publications, CA.

FORNELL, C.; LARCKER, D.F. (1981): "Evaluating structural equation models with unobservable variables and measurement error", Journal of Marketing Research, vol. 58: 39-50.

GABLE, G.; SEDERA, D.; CHAN, T. (2003): "Enterprise systems success: a measurement model", paper presented at the 24th conference of ICIS, Washington, United States.

GALANI, D.; GRAVAS, E.; STAVROPOULOS, A. (2010): “The impact of ERP systems on accounting processes", World Academy of Science, Engineering and Technology, vol. 66: 418-423. http://dx.doi.org/10.1108/14637150410530280

GERDIN, J. (2005): "Management accounting system design in manufacturing departments: an empirical investigation using a multiple contingencies approach", Accounting, Organizations and Society, vol. 30, n. 2: 99-126. http://dx.doi.org/10. 1016/j.aos.2003.11.003

GRANDE, E.U.; ESTEBANEZ, R.P.; COLOMINA, C.M. (2011): "The impact of Accounting Information Systems (AIS) on performance measures: empirical evidence in Spanish SME", International Journal of Digital Accounting Research, vol. 11: 25-43. http://dx.doi.org/10.4192/1577-8517-v11_2

GRANLUND, M. (2001): "Towards explaining stability in and around management accounting systems", Management Accounting Research, vol. 12, n. 2: 141-166. http://dx.doi.org/10.1006/mare.2000.0151

GRANLUND, M.; MALMI, T. (2002): "Moderate impact of ERPS on management accounting: a lag or permanent outcome?", Management Accounting Research, vol. 13, n. 3: 299-321. http://dx.doi.org/10.1006/mare.2002.0189 
GUIMARAES, T.; STAPLES, D.S.; MCKEEN, J.D. (2003): "Empirically testing some main user-related factors for systems development quality", Quality Management Journal, vol. 10, n. 4: 39-54.

GUL, F.A. (1991): "The effects of management accounting systems and environmental uncertainty on small business managers' performance", Accounting and Business Research, vol. 22, n. 85: 57-61. http://dx.doi.org/10.1080/00014788 .1991 .9729418

GUVENCE, C. (2005): "Information systems success and expectations for information technology investment: case study", Memory to obtain the Master of Science, Information System Department, Middle East Technical University, www.etd.lib.metu.edu.tr/upload/12605995/index.pdf. Accessed 29/06/2006.

HENDRICKS, K.B.; SINGHAL, V.R.; STARTMAN, J. (2007): “The impact of enterprise systems on corporate performance: a study of ERP, SCM, and CRM system implementations", Journal of Operations Management, vol. 25, n. 1: 6582. http://dx.doi.org/10.1016/j.jom.2006.02.002

HENSELER, J.; RINGLE, C.M.; SINKOVICS, R. (2009): “The use of partial least squares path modeling in international marketing", New Challenges to International Marketing Advances in International Marketing, vol. 20: 277-319. http://dx.doi.org/10.1108/S1474-7979 (2009)0000020014

HOLMES, S.; NICHLOS, D. (1988): "An analysis of the use of accounting information by Australian small business", Journal of Small Business Management, vol. 26, n. 2: 57-68.

IFINEDO, P.E. (2006): “Enterprise resource planning systems success assessment: an integrative framework", Doctoral thesis, Computer Sciences and Information Systems Department, Jyväskylä University, Finland.

IFINEDO, P.E. (2008): "Impacts of business vision, top management support, and external expertise on ERP success", Business Process Management Journal, vol. 14, n. 4: 551-568. http://dx.doi.org/10.1108/14637150810888073

IFINEDO, P.E.; NAHAR, N. (2007): "ERP systems success: an empirical analysis of how two organizational stakeholder groups prioritize and evaluate relevant measures", Enterprise Information Systems, vol. 1, n. 1: 25-48. http://dx.doi.org/10.1080/17517570601088539 
ISMAIL, N.A.; KING, M. (2007): "Factors influencing the alignment of accounting information systems in small and medium sized Malaysian manufacturing firms", Journal of Information Systems and Small Business, vol. 1, n.1-2: 1-20.

ISMAIL, N.A. (2009): "Factors influencing AIS effectiveness among manufacturing SMES: evidence from Malaysia", Electronic Journal on Information Systems in Developing Countries, vol. 38, n. 10: 1-19.

JIWAT, R.; MALCOM, P. (2009): "Exploring antecedents of organizational adoption of ERP and their effect on firm performance", paper presented at the $17^{\text {th }}$ European conference on information systems, www.ecis2009.it/papers/ecis20090314.pdf. Accessed 19/09/2010.

KANELLOU, A.; SPATHIS, C. (2011): “Accounting benefits and satisfaction in an ERP environment", paper presented at the $8^{\text {th }}$ international conference ICESAL, Enterprise Systems, Accounting and Logistics, Greece.

KARRUDDIN, S.; ASHHARI, Z.M.; NASSIR, A.M. (2010): "Information system and firms' performance: the case of Malaysian small medium enterprises", International Business Research, vol. 3, n. 4: 28-35.

KO, D.; KIRSCH, J.L.; KING, W.R. (2005): “Antecedents of knowledge transfer from consultants to clients in enterprise system implementations ", MIS Quarterly, vol. 29 , n. 1: 59-85.

LAVIGNE, B. (1999) : “Contribution à l'étude de la genèse des états financiers des PME”, Doctoral Thesis, Paris IX - Dauphine University, France.

LAVIGNE, B. (2002): "Système d'information comptable des PME: une recherche empirique", Revue Comptable et Financière, n. 348.

MALDONADO, M. (2009): "Factors impacting the success of ERP implementations in small and medium enterprises: an empirical assessment from Latin America", ESADE - PhD in Management Sciences Program. http://bit.ly/YnAAf4

MARKUS, L.M.; TANIS, C. (2000): "The enterprise systems experience-from adoption to success", in Framing the Domains of IT Research: Glimpsing the 
Future through the Past, RW Zmud, ed. Inc., Cincinnati, OH: Pinnaflex Educational Resources.

MIA, L. (1993): "The role of MAS information in organisations: an empirical study", British Accounting Review, vol. 25: 269-285. http://dx.doi.org/10.1006/ba $\underline{\text { re. } 1993.1026}$

MIA, L.; CHENHALL, R.H. (1994): “The usefulness of management accounting systems, functional differentiation and managerial effectiveness", Accounting, Organizations and Society, vol. 19, n. 1: 1-13. http://dx.doi.org/10.1016/03613682(94)90010-8

MOALLA, H. (2006): "La diffusion de la méthode ABC en Tunisie", halshs.archives-ouvertes.fr/docs/00/54/81/07/PDF/36-MOALLA.pdf.

MUSHAYT, O. (2000): "An empirical investigation of factors influencing the successful treatment of organizational issues in information systems development", doctoral thesis, Loughborough University, England.

NARANJO-GIL, D. (2004): "The role of sophisticated accounting system in strategy management", International Journal of Digital Accounting Research, vol. 4, n. 8: 125-144. http://dx.doi.org/10.4192/1577-8517-v4 5

NGONGANG, D. (2005): "Pratiques comptables, système d'information et performance des PME camerounaises", La Revue des Sciences de Gestion: Direction et Gestion, vol. 40, n. 216: 59-71. http://dx.doi.org/10.1051/larsg:20050 $\underline{44}$

NGONGANG, D. (2007): Analyse des facteurs déterminants du système d'information comptable et des pratiques comptables des PME tchadiennes", $L a$ Revue des Sciences de Gestion: Direction et Gestion, vol. 42, n. 224/225: 49-59. http://dx.doi.org/10.1051/larsg:2007017

NI, F.Y.; YANG, M.L.; CHENG, K.C. (2007): "The impact of management accounting systems on the relationship between product innovation and organizational performance". http://dx.doi.org/10.2139/ssrn.1003628

NUNALLY, J.C. (1978): “Psychometric theory”, McGraw-Hill, New York.

RAMAYAH, T.; ROY, M.H., AROKIASAMY, S.; ZBIB, I.; AHMED, Z.U. (2007): "Critical success factors for successful implementation of enterprise 
resource planning systems in manufacturing organizations", International Journal of Business Information Systems, vol. 2, n. 3: 276-297. http://dx.doi.org/10.1504/I JBIS.2007.011980

RINGLE, C.M.; WENDE, S.; WILL, A. (2005): “SmartPLS 2.0 M3”, Available at: http:// www.smartpls.de

ROM, A. (2008): "Management accounting and integrated information systems: how to exploit the potential for management accounting of information technology", $\mathrm{PhD}$ Series, Copenhagen Business School, 302 pg.

SABHERWAL, R.; JEYARAJ, A.; CHOWA, C. (2006): "Information system success: individual and organizational determinants", Management Science, vol. 52, n. 12; 1849-1864. http://dx.doi.org/10.1287/mnsc.1060.0583

SAEED, K.A.; ABDINNOUR-HELM, S. (2008): "Examining the effects of information system characteristics and perceived usefulness on post adoption usage of information systems", Information \& Management, vol. 45: 376-386. http://dx.doi.org/10.1016/j.im.2008.06.002

SALEHI, M.; ROSTAMI, V.; MOGADAM, A. (2010): "Usefulness of accounting information system in emerging economy: empirical evidence of Iran”, International Journal of Economics and Finance, vol. 2, n. 2: 186-195. http://bit.ly/YnBFDO

SCAPENS, R.W.; JAZAEYRI, M. (2003): "ERP systems and management accounting change: opportunities or impact?", European Accounting Review, vol. 12, n. 1: 201-233. http://dx.doi.org/10.1080/0963818031000087907

SEDERA, D.; GABLE, G. ; CHAN, T. (2003) : "Measuring enterprise systems success: a preliminary model", Paper presented at the $9^{\text {th }}$ Americas conference on information systems, pp. 476-485. http://bit.ly/X3NQ7r

SPATHIS, C.; CONSTATINIDES, S. (2004): "Enterprise resource planning systems' impact on accounting processes", Business Process Management Journal, vol. 10, n. 2: 234-251. http://dx.doi.org/10.1108/14637150410530280

STEPNIEWSKI, J.; SOUID, S.; AZZABI, L. (2008): “La relation facteurs de contingence, complexité du système d'information comptable et performance 
financière". www.scribd.com/doc/51654351/La-relation-facteurs-de-contingence. Accessed 06/11/2010.

SULAIMAN, S.; RAMLI, A.; MITCHELL, F. (2008): "What factors drive changes in management accounting in Malaysian organizations?", Malaysian Accounting Review, vol. 7, n. 1: 61-76.

TSUI, J.S. (2001): "The impact of culture on the relationship between budgetary participation, management accounting systems, and managerial performance: an analysis of Chinese and Western managers", International Journal of Accounting, vol. 36, n. 2: 125-146. http://dx.doi.org/10.1016/S0020-7063(01)00101-7

VELCU, O. (2007): "Exploring the effects of ERP systems on organizational performance - evidence from Finnish companies", Industrial Management \& Data Systems, vol. 107, n. 9: 1316-1334. http://dx.doi.org/10.1108/02635570710 $\underline{833983}$

WANG, E. (2003): "Effect of the fit between information processing requirements and capacity on organizational performance", International Journal of Information Management, vol. 23, n. 3: 239-247. http://dx.doi.org/10.1016/S0268 -4012(02)00106-8

WANG, E.; CHEN, J. (2006): "Effects of internal support and consultant quality on the consulting process and ERP system quality", Decision Support Systems, vol. 42, n. 2: 1029-1041. http://dx.doi.org/10.1016/j.dss.2005.08.005

WANG, E.; SHIH, S.P., JIANG, J.; KLEIN, G. (2008): “The consistency among facilitating factors and ERP implementation success: a holistic view of fit", Journal of Systems and Software, vol. 81: 1609-1621. http://dx.doi.org/10.1016/j.j $\underline{\text { ss.2007.11.722 }}$

XU, H.; (2003): “Critical Success Factors for Accounting Information Systems Data Quality", doctoral thesis, Southern Queensland University, Australia.

YU, C.S. (2005): "Causes influencing the effectiveness of the postimplementation ERP system", Industrial Management \& Data System, vol. 105, n. 1: 115-132. http://dx.doi.org/10.1108/02635570510575225

ZHANG, Z.; LEEB, M.K.O.; HUANG, P.; ZHANG, L.; HUANG, X. (2005): “A framework of ERP systems implementation success in China: an empirical study", 
International Journal of Production Economics, vol. 98, n. 1: 56-80. http://dx.doi.org/10.1016/j.ijpe.2004.09.004 